\title{
20: 14266270-14252643
}

National Cancer Institute

\section{Source}

National Cancer Institute. 20:14266270-14252643. NCI Thesaurus. Code C42281.

Physical location of FLRT3_Gene 